\section{Commercial Greenhouse Growers Can Produce High-quality Bedding Plants in Bioplastic-based Biocontainers}

\author{
Nicholas J. Flax ${ }^{1}$, Christopher J. Currey ${ }^{1,3}$, James A. Schrader ${ }^{1}$, \\ David Grewell ${ }^{2}$, and William R. Graves ${ }^{1}$
}

ADDITIONAL INDEX WORDs. angelonia, floriculture, geranium, lignin, polyhydroxyalkanoates, polylactic acid, soy polymer

\begin{abstract}
SUMMARY. Our objectives were to quantify the growth and quality of herbaceous annuals grown in different types of bioplastic-based biocontainers in commercial greenhouses and quantify producer interest in using these types of biocontainers in their production systems. Seedlings of 'Serena White' angelonia (Angelonia angustifolia) and 'Maverick Red' zonal geranium (Pelargonium $\times$ bortorum) that had been transplanted into nine different $(4.5$-inch diameter) container types [eight bioplastic-based biocontainers and a petroleum-based plastic (PP) (control)] were grown at six commercial greenhouses in the upper midwestern United States. Plants were grown alongside other bedding annuals in each commercial greenhouse, and producers employed their standard crop culture practices. Data were collected to characterize growth when most plants were flowering. Questionnaires to quantify producer perceptions and interest in using bioplastic-based biocontainers, interest in different container attributes, and satisfaction were administered at select times during the experiment. Container type interacted with greenhouse to affect angelonia growth index (GI) and shoot dry weight (SDW), as well as shoot, root, and container ratings. Container type or greenhouse affected geranium GI and shoot rating, and their interaction affected SDW, and root and container ratings. These results indicate that commercial producers can grow herbaceous annuals in a range of bioplastic-based biocontainers with few or no changes to their crop culture practices.
\end{abstract}

A nnual bedding and garden plants made up $44 \%$ ( $\$ 2.56$ billion) of all floriculture sales in 2014 ( $\$ 5.87$ billion) [U.S. Department of Agriculture (USDA), 2015]. Nearly 600 million containerized plants, not including flats and hanging baskets, accounted for $49 \%$ ( $\$ 1.25$ billion) of annual bedding and garden plant sales. Sixty-nine percent (416 million) of these units were produced in containers less than 5 inches in diameter. Horticultural containers are typically manufactured from PPs. Using the calculations of

We gratefully acknowledge Bailey Nurseries, Dalla Johnson Greenhouses, DeJong Greenhouses, Plantpeddler Greenhouses, Swift Greenhouses, and Tangletown Gardens and all affiliated grower participants for their contributions to this experiment. We also thank Kellie Walters, Kenneth McCabe, Brianna Vest, and Alexander Litvin for experiment setup and data collection assistance, and the USDA Specialty Crops Research Initiative and the National Institute of Food and Agriculture for funding.

${ }^{1}$ Department of Horticulture, Iowa State University, 106 Horticulture Hall, Ames, IA 50011

${ }^{2}$ Department of Materials Science and Engineering, Iowa State University, 4356 Elings Hall, Ames, IA 50011

${ }^{3}$ Corresponding author. E-mail: ccurrey@iastate.edu. doi: 10.21273/HORTTECH03616-16
Schrader, (2013), updated with data from 2014 (U.S. Department of Agriculture, 2015), $4790 \mathrm{t}$ of $\mathrm{PP}$ was used to produce more than 400 million containers less than 5 inches in diameter that were used for annual bedding and garden plant production in 2014. With the intensive use of PP, waste disposal, and greater concerns for environmental impacts (Evans et al., 2010), commercial bedding plant producers may choose or be required to use containers made from renewable materials.

Horticultural containers are predominately manufactured from PPs owing to their relatively low cost, strength, and availability in numerous shapes and sizes (Evans and Hensley,
2004; Hall et al., 2010; Helgeson et al., 2009). Biodegradable or compostable plant containers (often referred to as biocontainers) offer an alternative to petroleum plastic containers in container crop production (Kuehny et al., 2011). Compared with PP containers, fiber-based biocontainers have relatively poor wateruse efficiency and durability, which can reduce plant growth and marketability, respectively (Evans et al., 2015; Koeser et al., 2013a; McCabe et al., 2014). Therefore, development of biocontainers with properties that are more similar to PP containers would be beneficial.

Bioplastics and biocomposites (plastics blended with bio-based fillers) are potential substitutes for PPs in the manufacture of horticultural containers (Grewell et al., 2014). Through several phases of material development (Liu et al., 2015; Lu et al., 2014; Madbouly et al., 2014; Yang et al., 2015) and greenhouse trials (Currey et al., 2015; Kratsch et al., 2015; McCabe et al., 2014), we identified bioplastics and composites that can be effectively molded into horticultural containers suitable for greenhouse crop production (Grewell et al., 2014). Whereas commercially available bioplastic containers can yield plants of high quality compared with plants grown in PP containers (Conneway et al., 2015; Helgeson et al., 2009; Lopez and Camberato, 2011), our research is the first to report on the effectiveness of novel bioplastic-based biocontainers evaluated by producers.

Trials in commercial settings can evaluate the efficacy of new technologies in commercial production systems (Chappell et al., 2013; Meng and Runkle, 2014). Ease of implementation was identified as the most significant barrier to commercial producers adopting sustainable technologies and practices (Hall et al., 2009). Therefore, our objectives were to

\begin{tabular}{llll}
\hline $\begin{array}{l}\text { Units } \\
\text { To convert U.S. to SI, } \\
\text { multiply by }\end{array}$ & U.S. unit & SI unit & $\begin{array}{l}\text { To convert SI to U.S., } \\
\text { multiply by }\end{array}$ \\
\hline 2.54 & inch(es) & $\mathrm{cm}$ & 0.3937 \\
16.3871 & inch $^{3}$ & $\mathrm{~cm}^{3}$ & 0.0610 \\
0.5933 & $\mathrm{lb} / \mathrm{yard}^{3}$ & $\mathrm{~kg} \cdot \mathrm{m}^{-3}$ & 1.6856 \\
28.3495 & $\mathrm{Oz}$ & $\mathrm{g}$ & 0.0353 \\
1 & $\mathrm{ppm}$ & $\mathrm{mg} \cdot \mathrm{L}^{-1}$ & 1 \\
$\left({ }^{\circ} \mathrm{F}-32\right) \div 1.8$ & ${ }^{\circ} \mathrm{F}$ & ${ }^{\circ} \mathrm{C}$ & $\left({ }^{\circ} \mathrm{C} \times 1.8\right)+32$
\end{tabular}


evaluate our bioplastic-based biocontainers in commercial greenhouses by 1) quantifying growth of herbaceous annuals grown in different container types, and 2) characterizing commercial producers' interest in using these bioplastic-based biocontainers through a series of questionnaires and qualitative evaluations of plant, root, and container quality.

\section{Materials and methods}

Container TYPes. Nine types of 4.5-inch-diameter containers were used, including eight bioplastic-based biocontainers and a PP (control) container (Table 1). Based on positive results regarding plant growth, plant health ratings, and container performance (Currey et al., 2015; Kratsch et al., 2015; McCabe et al., 2014), seven types of 4.5-inch-diameter $\left(40.0\right.$ inch $\left.^{3}\right)$ injection-molded bioplastic containers $\left(V_{\text {VistaTek }}{ }^{\circledR}\right.$; Stillwater, $\mathrm{MN}$ ) and paper fiber containers (36.6 inch $^{3}$; Myers Industries, Akron, $\mathrm{OH}$ ) dip-coated twice with biopolyurethane (PUR) were chosen for evaluation. Injection-molded bioplastic containers were manufactured with different proportions (by weight) of polylactic acid [PLA (a widely available commercial bioplastic)], polyhydroxyalkanoates [PHA (a lesscommon commercial bioplastic)], soy polymer with adipic anhydride
[SP.A (a soy protein-based bioplastic developed at Iowa State University)], dried distiller's grains and solubles [DDGS (a coproduct of corn ethanol production)], a proprietary bio-based filler (BR) derived from processed DDGS (BioRes ${ }^{\mathrm{T}}$; Laurel Biocomposite, Laurel, NE), or lignin powder. Containers manufactured from PLA and SP.A, and lower or higher proportions (by weight) of $B R$ relative to other components are denoted by subscripts (PLA-SP.A-BR low $_{\text {or PLA- }}$ SP.A-BR high, $_{\text {, respectively). Containers }}$ represented a spectrum of degradability from highly durable to biodegradable in soil within 1-2 years (Table 1).

EXPERIMENTAL DESIGN, GREENHOUSE FACILITIES, AND CULTURE. This experiment was conducted using a randomized complete block design in factorial arrangement with greenhouse (six levels) and container type (nine levels) as factors. Each 10-cell shuttle tray was a replicate $(n=3$ per container type per greenhouse) and individual containers from each tray were subreplicates. Plants were blocked by species at each greenhouse to accommodate different cultural requirements (Table 2) for each crop.

Seedlings of 'Serena White' angelonia and 'Maverick Red' zonal geranium were grown at Iowa State
University, Ames, IA (lat. $42^{\circ} \mathrm{N}$ ), in 288 -cell propagation trays $(0.43$ inch $^{3}$ cell vol.; T.O. Plastics, Clearwater, MN). Experiment plots were set up between 16 and 20 Mar. 2015 at six commercial greenhouses in the upper midwestern United States (coded as greenhouses A through F). Three out of six facilities were strictly wholesale greenhouses, whereas the others were primarily wholesale with some retail. Soilless substrate composed of (by vol.) $75 \%$ sphagnum peatmoss and $25 \%$ perlite (Sunshine Mix \# 1; Sun Gro Horticulture, Agawam, MA) was taken to greenhouses A, B, D, and E. Greenhouses $\mathrm{C}$ and $\mathrm{F}$ supplied their own soilless substrate amended with controlledrelease fertilizer, as this was their primary means of delivering mineral nutrients to annual bedding plants. Containers were filled and one seedling was transplanted into each container. Containers were placed into PP shuttle trays, as this is typical of small-container crop production in commercial greenhouses. Each 10cell shuttle tray was composed of only a single container type per tray, and trays were randomized within species at each greenhouse. Both species were grown adjacent to one another in the same growing space.

Environment data loggers (Watchdog Plant Growth Station

Table 1. 'Serena White' angelonia and 'Maverick Red' zonal geranium were grown in eight types of 4.5-inch (11.43 $\mathrm{cm})$ diameter bioplastic-based biocontainers and a petroleum-based plastic [PP (control)] in a commercial greenhouse grower trial at six greenhouses in the upper midwestern United States. Parent materials of bioplastic containers included polylactic acid [PLA (commercially available bioplastic)], a proprietary bio-based filler (BR) derived from processed dried distiller's grains and solubles, lignin powder, soy bioplastic with adipic anhydride [SP.A (developed at Iowa State University)], polyhydroxyalkanoates [PHA (commercially available bioplastic)], dried distiller's grains and solubles [DDGS (a coproduct of corn ethanol production)], recycled PLA (rPLA), castor oil-based biopolyurethane (PUR), plasticizers to aid the injection molding process, and coloring agents. Relevant attributes intrinsic to containers are listed, including percentages of different parent materials used to manufacture, "fertilizer effect" identified by Schrader et al. (2013), and degradability of containers.

\begin{tabular}{lccc}
\hline Container type $^{\mathbf{z}}$ & Proportions of materials (\% by wt, respectively) & Fertilizer effect $^{\mathbf{y}}$ & Container degradability $^{\mathbf{x}}$ \\
\hline PLA-lignin & $90 / 10$ & No & Durable \\
rPLA & 100 & No & Durable \\
PUR & $-{ }^{\mathrm{w}}$ & No & Biodegradable \\
PHA-DDGS & $80 / 20$ & No & Biodegradable \\
PLA-BR & $80 / 20$ & No & Compostable \\
PLA-SP.A & $60 / 40$ & Yes & Compostable \\
PLA-SP.A-BR & $55 / 35 / 10$ & Yes & Compostable \\
PLA-SP.A-BR & $50 / 30 / 20$ & Yes & Compostable \\
PP & 100 & No & Nondegradable \\
\hline
\end{tabular}

${ }^{\mathrm{z}}$ Container types are blends of different ratios of bioplastic and biocomposite materials; $\mathrm{BR}_{\mathrm{low}}$ and $\mathrm{BR}$ high denote the relative proportion of BR to other container materials. ${ }^{y}$ Containers manufactured with SP.A release plant-available mineral nutrients as containers degrade (Schrader et al., 2013 ).

${ }^{\mathrm{x}}$ Degradability of bioplastic-based biocontainers as characterized by Schrader et al. (2015); biodegradable = biodegradable in soil within $1-2$ years, compostable $=$ nondegradable in soil but degradable by composting, durable = durable containers that improve on sustainability while requiring little or no change in cultural practices, nondegradable $=$ noncompostable or biodegradable.

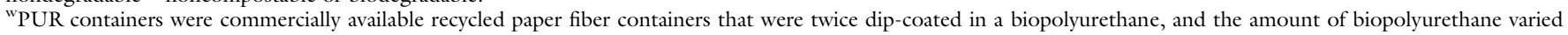
between containers. 
model 2475; Spectrum Technologies, Aurora, IL) were placed among plants to record daily light integral and average daily temperature throughout production (Table $2)$. Cultural practices including fertilizer source and concentration, supplemental lighting, and any plant growth retardant (PGR) applications were documented by grower participants in charge of managing crops (Table 2).

DatA COLLECTION AND CALCULATION. Institutional Review
Board-approved questionnaires were administered to commercial-grower participants; only growers in charge of managing the experiment were surveyed. A preproduction questionnaire that characterized each grower's perceptions of and interest in using biocontainers was administered to each participant before planting seedlings (Table 3). Upon completion of growing both species, the same questionnaire (postproduction) was administered again, along with two questionnaires that evaluated grower participant satisfaction with performance of our bioplastic-based containers and interest in different attributes intrinsic to the containers (Tables 4 and 5 , respectively).

For each species, when $75 \%$ of each species at a given greenhouse had open flowers, growers were asked to rate shoot, root, and container quality. Independent Likert scale ratings on a scale of 1 to $5(1=$ worst, $5=$ best) were assigned via a single-blind evaluation, where container types that shoots and root systems came from

Table 2. Facility, environmental parameters, and crop culture practices that were recorded, including average daily temperature (ADT), daily light integral (DLI), fertilizer source [water soluble (WSF) or controlled-release (CRF)], analysis, and percent nitrogen $(\mathrm{N})$, phosphorous $(\mathrm{P})$, and potassium $(\mathrm{K})$ concentrations, supplemental lighting, and plant growth retardants (PGRs) applied for 'Serena White' angelonia and 'Maverick Red' zonal geranium grown in eight types of 4.5-inch $(11.43 \mathrm{~cm})$-diameter bioplastic-based biocontainers and a petroleum-based plastic (control) in a commercial greenhouse grower trial at six greenhouses in the upper midwestern United States. Irrigations with clear water occurred between applications of WSF to crops.

\begin{tabular}{|c|c|c|c|c|c|}
\hline Greenhouse & $\begin{array}{c}\text { ADT } \\
{\left[\text { mean } \pm \text { SD }\left({ }^{\circ} \mathbf{F}\right)\right]^{\mathrm{z}}}\end{array}$ & $\begin{array}{c}\text { DLI } \\
\left(\mathrm{mol} \cdot \mathrm{m}^{-2} \cdot \mathrm{d}^{-1}\right)\end{array}$ & $\begin{array}{c}\text { Fertilizer } \\
(\text { source, } \mathrm{N}-\mathrm{P}-\mathrm{K}, \text { concn })^{\mathrm{z}}\end{array}$ & $\begin{array}{l}\text { Supplemental } \\
\text { lighting }\end{array}$ & $\begin{array}{l}\text { PGRs (species: active } \\
\text { ingredient, concn, } \\
\text { no. applications) }\end{array}$ \\
\hline A & $63.7 \pm 8.1$ & 20.5 & $\begin{array}{l}\text { WSF, } 20 \mathrm{~N}-4.4 \mathrm{P}-17.6 \mathrm{~K} \\
125 \mathrm{ppm} \mathrm{N}\end{array}$ & No & $\begin{array}{l}\text { Angelonia: daminozide, } \\
2500 \mathrm{ppm}, 1 \times \\
\text { Geranium: chlormequat } \\
\text { chloride, } 500 \mathrm{ppm}, 2 \times\end{array}$ \\
\hline $\mathrm{C}$ & $67.4 \pm 7.0$ & 11.2 & $\begin{array}{l}\mathrm{CRF}^{\mathrm{y}}, 17 \mathrm{~N}-2.2 \mathrm{P}-9.7 \mathrm{~K} \\
5 \mathrm{lb} / \mathrm{yard}^{3}\end{array}$ & No & $\begin{array}{l}\text { Angelonia: plants were pinched } \\
10 \mathrm{~d} \text { after planting }\end{array}$ \\
\hline $\mathrm{D}$ & $69.5 \pm 6.5$ & 13.9 & $\begin{array}{l}\text { WSF, 16N-1.3P-14.1K, } \\
200 \text { ppm N }\end{array}$ & No & Not applied \\
\hline $\mathrm{E}$ & $68.9 \pm 5.2$ & 17.1 & $\begin{array}{l}\text { WSF, } 17 \mathrm{~N}-0 \mathrm{P}-15 \mathrm{~K}, 140 \\
\text { ppm N and } \mathrm{MKP}^{\mathrm{x}} \\
10 \mathrm{ppm} \mathrm{P}\end{array}$ & Yes & $\begin{array}{l}\text { Geranium: daminozide }+ \\
\text { chlormequat chloride } \\
3750+500 \text { ppm, } 3 \times\end{array}$ \\
\hline
\end{tabular}

${ }^{\mathrm{z}}\left({ }^{\circ} \mathrm{F}-32\right) \div 1.8={ }^{\circ} \mathrm{C}, \mathrm{l} \mathrm{ppm}=1 \mathrm{mg} \cdot \mathrm{L}^{-1}, \mathrm{l} \mathrm{lb} / \mathrm{yard}^{3}=0.5933 \mathrm{~kg} \cdot \mathrm{m}^{-3}$.

y In-house soilless substrate with CRF incorporated was used in place of the soilless substrate brought to the other facilities as this was the primary source of mineral nutrients in their normal bedding annual cropping scheme.

${ }^{\mathrm{x}}$ Monopotassium phosphate.

Table 3. Grower perceptions of and interest in using bioplastic-based plant containers before (pre) and after (post) producing 'Serena White' angelonia and 'Maverick Red' zonal geranium in eight types of 4.5-inch ( $11.43 \mathrm{~cm})$-diameter bioplastic-based biocontainers and a petroleum-based plastic (control) at six greenhouses in the upper midwestern United States. Changes in grower perceptions and interest in using biocontainers in their commercial production schemes between pre- and postproduction questionnaires were detected using Wilcoxon's signed rank test.

\begin{tabular}{|c|c|c|c|}
\hline \multirow[b]{2}{*}{ Question } & \multicolumn{3}{|c|}{ Response ( $1-4$ scale) } \\
\hline & Pre & Post & Significance $^{\mathrm{z}}$ \\
\hline I am ___ in using biocontainers in containerized greenhouse crop production ${ }^{y}$ & 3.3 & 3.0 & NS \\
\hline I am __ that I can produce a high-quality crop of plants in biocontainers ${ }^{\mathrm{x}}$ & 3.0 & 3.2 & NS \\
\hline $\begin{array}{l}\text { The appearance of a biocontainer } \\
\text { a high-quality crop of plants in biocontainers }{ }^{\mathrm{w}}\end{array}$ & 2.2 & 2.3 & NS \\
\hline
\end{tabular}

${ }^{\mathrm{z}}$ Significance using Wilcoxon's signed rank test; NS = nonsignificant.

y Likert scale response: 1 = very uninterested, 2 = uninterested, $3=$ interested 4 = very interested.

${ }^{x}$ Likert scale response: $1=$ very unconvinced, $2=$ unconvinced, $3=$ convinced, $4=$ very convinced.

${ }^{w}$ Likert scale response: 1 = really does not affect, $2=$ does not affect, $3=$ affects, $4=$ strongly affects. 
Table 4. Growers' satisfaction after producing 'Serena White' angelonia and 'Maverick Red' zonal geranium in eight types of 4.5 -inch $(11.43 \mathrm{~cm})$-diameter bioplastic-based biocontainers and a petroleum-based plastic (control) at six greenhouses in the upper midwestern United States. Responses from commercial grower participants were positive, indicated that growers liked producing crops in bioplastic-based plant containers, and that container performance exceeded their expectations.

\begin{tabular}{|c|c|c|c|c|c|c|}
\hline \multirow[b]{3}{*}{ Question } & \multicolumn{6}{|c|}{ Response ( $1-4$ scale $)$} \\
\hline & \multicolumn{6}{|c|}{ Grower } \\
\hline & A & B & $\mathbf{C}$ & $\mathbf{D}$ & $\mathbf{E}$ & $\mathbf{F}$ \\
\hline How did you like growing plants in the biocontainers provided?y & 3.0 & 3.0 & 4.0 & 3.0 & 3.0 & 4.0 \\
\hline
\end{tabular}

${ }^{\mathrm{z}}$ Likert scale response: 1 = did not meet expectations by far, $2=$ did not meet expectations, $3=$ exceeded expectations, $4=$ exceeded expectations by far.

${ }^{y}$ Likert scale response: 1 = really did not like, 2 = did not like, $3=$ liked, 4 = really liked.

Table 5. Commercial greenhouse growers demonstrated interest in a range of intrinsic physical and chemical properties, categorized by Schrader et al. (2015), after producing 'Serena White' angelonia and 'Maverick Red' zonal geranium in eight types of 4.5 -inch $(11.43 \mathrm{~cm})$-diameter bioplastic-based biocontainers and a petroleum-based plastic (control) at six greenhouses in the upper midwestern United States. Responses were pooled across greenhouses $(n=6)$ and mean separations were performed using Tukey's honestly significant difference test.

Question Response (1-4 scale $)^{\mathrm{z}}$

Would you be interested in a container that biodegrades quickly in soil when $3.5 \mathrm{a}^{\mathrm{y}}$ planted with the container?

Would you be interested in a biocontainer that biodegrades when placed into the compost? 3.5 a

Would you be interested in a biocontainer that releases fertilizer during greenhouse production

(i.e., nitrogen, phosphorus, potassium)?

Would you be interested in a biocontainer that reduces circling root formation?

Would you be interested in a biocontainer that appears nearly identical to petroleum plastic containers?

$3.2 \mathrm{a}$

Would you be interested in a biocontainer if it were not made of $100 \%$ bio-based materials?

$2.7 \mathrm{a}$

Would you be interested in a biocontainer if it appeared identical to a colored petroleum plastic

$3.0 \mathrm{a}$

container, but the coloring agent was not bio-based material?

${ }^{\mathrm{z}}$ Likert scale responses: 1 = very uninterested, 2 = uninterested, $3=$ interested, 4 = very interested.

${ }^{\mathrm{y}}$ Means that share letters are similar by Tukey's honestly significant difference test at $P \leq 0.05$.

were concealed from grower participants. Plants sampled for shoot ratings were placed into unused PP containers as a blinding measure. Grower participants were asked to rate shoots one at a time based on plant size, greenness, abundance or absence of flowers, signs of chlorosis or necrosis, stunting, or abnormal growth (Schrader et al., 2013). Plants with shoots rated 1.0 were considered unsalable, whereas plants with a 5.0 rating were considered premium quality. Containers and shoots were removed, as a blinding measure, when growers evaluated root profiles. Root ratings were assigned based on robustness of root system, root morphology characteristics such as branching, color, fibrousness, circling or root-bound habit, or the presence of pathogen symptoms. Root ratings of 1.0 were considered very poor in health, whereas roots rated 5.0 were considered to be in excellent health. Empty, used containers were rated based on discoloration, durability, ease of handling, and the presence of microbial growth or arthropods colonizing the container surface.
Containers rated 1.0 were considered very undesirable, whereas containers rated 5.0 were considered very desirable. Information on the different container types and container parent materials was withheld from growers until the conclusion of the experiment to avoid bias. Grower participants were instructed to assign ratings objectively and not compare shoots, roots, or containers with other samples.

Plant growth data were collected after final grower ratings were assigned. Height from the substrate surface to the tallest growing point, widest diameter (diameter 1), and width $90^{\circ}$ from the widest diameter (diameter 2) were collected from five randomly selected plants (subreplicates) in each shuttle tray. Growth index, an integrated measurement of plant height and width (Jeong et al., 2009), was calculated for each plant. $\mathrm{GI}=\{$ plant height $+[($ diameter $1+$ diameter 2)/2]\}/2. Shoots were severed at the substrate surface, dried, and average SDW was calculated.

STATISTICAL ANALYSIs. The effects of container type and greenhouse on plant growth (GI, SDW) and quality of plant shoots, roots, and containers were evaluated using analysis of variance (Table 6). Analyses were performed for each species separately using PROC GLM of SAS (version 9.4; SAS Institute, Cary, NC). Mean separations for plant growth parameters, quality ratings, and bioplastic-based container attributes were performed using Tukey's honestly significant difference test at $P$ $\leq 0.05$. Nonparametric analysis (Wilcoxon's signed rank test) was performed using PROC UNIVARIATE of SAS to detect differences in perceptions and interest in using biocontainers pre- and postplant production.

\section{Results}

Angelonia. Container type and greenhouse interacted to affect shoot, root, and container quality ratings (Table 6). For instance, there were no differences in shoot quality across container types within greenhouses A or $\mathrm{E}$ whereas differences were observed at other greenhouses (Table 7). Alternatively, across greenhouses, 
Table 6. Analyses of variance for container type $(C)$ and greenhouse (G) on growth index (GI), shoot dry weight (SDW), and quality of shoots, roots and containers of 'Serena White' angelonia and 'Maverick Red' zonal geranium grown in eight types of 4.5-inch $(11.43 \mathrm{~cm})$-diameter bioplasticbased biocontainers and a petroleum-based plastic (control) at six greenhouses in the upper midwestern United States. Significance of main effects and interactions were detected using PROC GLM of SAS (version 9.4; SAS Institute, Cary, NC).

\begin{tabular}{lccc}
\hline Parameter & C & G & C $\times$ G \\
\hline GI & \multicolumn{3}{c}{ Angelonia } \\
SDW & $* * * z$ & $* * *$ & $* *$ \\
Shoot rating & $* *$ & $* * *$ & $* * *$ \\
Root rating & $* * *$ & $* * *$ & $* * *$ \\
Container rating & $* * *$ & $* * *$ & $* * *$ \\
& & &
\end{tabular}

\begin{tabular}{lccc} 
& \multicolumn{3}{c}{ Geranium } \\
GI & $* * *$ & $* * *$ & NS \\
SDW & $*$ & $* * *$ & $* *$ \\
Shoot rating & $* *$ & $* * *$ & NS \\
Root rating & $* * *$ & $* * *$ & $* * *$ \\
Container rating & $* * *$ & $* * *$ & $* * *$
\end{tabular}

${ }_{\mathrm{NS}}, *, * *, * * *$ Nonsignificant or significant at $P \leq 0.05$, 0.01 , or 0.001 , respectively.

shoot ratings of plants grown in PLASP.A-BR high containers were lower at greenhouses $\mathrm{C}$ and $\mathrm{D}$ compared with greenhouses $\mathrm{A}$ and $\mathrm{E}$, whereas shoots of plants grown in PLA-BR were rated similarly at all six greenhouses. Roots of plants at greenhouse D grown in PLA-lignin containers were rated similarly to those in PLA-BR containers, but not at any other greenhouses. Conversely, within container types, roots of plants grown in PLA-BR containers were rated higher at greenhouse D than greenhouses B, C, and $\mathrm{F}$, whereas plants grown in PP containers received similar root ratings at all greenhouses. PHA-DDGS containers were rated similarly to PP at greenhouse $\mathrm{E}$ but not greenhouse C. Alternately, PHA-DDGS container ratings varied considerably across greenhouses (1.0-5.0), whereas PLA-lignin containers were rated the same (5.0) at all six greenhouses.

Container type and greenhouse also interacted to affect GI and SDW (Table 6). For example, there were no differences in GI across different containers within greenhouses A, B, and
F, whereas GI of plants grown in PLA-SP.A-BR high containers were smallest (14.8-16.4) across container types within greenhouses $\mathrm{C}, \mathrm{D}$, and $\mathrm{E}$ (Table 7). Alternatively, GI of plants grown in PLA-SP.A-BR $\mathrm{BR}_{\text {high }}$ containers at greenhouse E (14.8) were smaller than greenhouse A (20.6), but plants at both greenhouses were similar when grown in PLA-lignin containers (18.8 and 18.4, respectively). Similarly, no differences in SDW across container types were observed within greenhouses A, B, and $\mathrm{F}$, whereas SDW was lowest (1.4-1.8 g) for plants grown in PLASP.A-BR high $_{\text {containers at green- }}$ houses C, D, and E. Conversely, SDW of plants grown in PLA-SP.A containers were similar at greenhouses $\mathrm{A}$ and $\mathrm{F}$ (2.5 and $2.3 \mathrm{~g}$, respectively), but plants grown in PUR containers were larger at greenhouse A (3.5 g) than at greenhouse $\mathrm{F}(1.7 \mathrm{~g})$.

Geranium. Container type or greenhouse affected the shoot quality (Table 6). For instance, shoot ratings across container types ranged from 3.4 (PLA-lignin and PUR) to 4.2 (PLA-SP.A-BR low $_{\text {) }}$ (Table 8), whereas differences across greenhouses ranged from 3.3 at greenhouses $\mathrm{B}$ and $\mathrm{C}$ to 4.4 at greenhouse $\mathrm{E}$ (Table 9). Container type interacted with greenhouse location to affect root and container ratings ( $\mathrm{Ta}-$ ble 6). As an example, roots of plants grown in PLA-SP.A and PP containers were rated similarly within greenhouse $B$ but were rated differently at greenhouse F (Table 10). Alternatively, roots of plants grown in PP containers were similar at greenhouses $\mathrm{B}$ and $\mathrm{F}$, whereas roots of plants grown in PLA-SP.A (60/ $40)$ containers were rated higher at greenhouse $\mathrm{B}$ than at greenhouse $\mathrm{F}$. Polylactic acid-lignin containers received the highest container ratings, rated 5.0 at five facilities and 4.0 at the other. Alternatively, PLA-BR, PLA-SP.A-BR, and PHADDGS were not rated consistently, receiving the highest rating $(5.0)$ at one facility and the lowest (1.0) at another.

Greenhouse or container type affected GI and their interaction affected SDW (Table 6). Plants grown in PLA-SP.A-BR high or PLA-SP.A containers had the largest GI (22.6 and 22.7, respectively), whereas plants grown in PHA-DDGS containers were smallest (19.9) (Table 8 ). Growth index of plants at greenhouse C (26.6) was 31\% larger than greenhouses D and E (18.3) (Table 8). No differences in SDW were observed across container types within greenhouse $\mathrm{A}, \mathrm{B}, \mathrm{C}, \mathrm{E}$, and $\mathrm{F}$, whereas at greenhouse $\mathrm{D}$, plants produced in PHA-DDGS $(2.9 \mathrm{~g})$ were $15 \%$ to $34 \%$ smaller than other container types (Table 10). Alternatively, within container types, plants grown in PUR containers had similar SDW at all greenhouses except greenhouse $\mathrm{D}$, whereas SDW of plants grown in PHA-DDGS containers were lowest at greenhouse $\mathrm{D}$ and highest at greenhouse C.

Questionnaires. Perceptions of and interest in using biocontainers did not change during the experiment (Table 3 ). For example, on a Likert scale of 1 to 4 ( 1 = very uninterested, $4=$ very interested), the average response when interest in using biocontainers was assessed was 3.3 (pre) and 3.0 (post) out of 4 . Responses to the questionnaire on satisfaction using bioplastic-based biocontainers were positive (Table 4 ), and expectations were exceeded. On a scale of 1 to $4(1=$ very uninterested, $2=$ uninterested, $3=$ interested, $4=$ very interested), growers were interested in different attributes intrinsic to our bioplastic-based biocontainers; however, no single attribute was found to be of greater interest to participants (Table 5).

\section{Discussion}

Plants produced in our bioplasticbased biocontainers were generally of similar quality and size compared with plants grown in PP containers. Shoots of angelonia grown in all container types were rated similarly to those of plants grown in PP containers at five out of six greenhouses (Table 7). Similarly, GI and SDW of angelonia grown in bioplastic-based containers were almost always similar to plants grown in PP containers (Table 7). Shoot ratings and GI of geraniums produced in all bioplasticbased container types were always similar to or greater than those of plants grown in PP containers (Table 8 ), and SDW of geranium was similar to plants grown in PP containers at five out of six greenhouse locations (Table 10). Our findings agree with other researchers' results where 
Table 7. Grower quality ratings for shoots and flowers, root systems, and containers, growth index, and shoot dry weight of 'Serena White' angelonia produced in eight types of 4.5 -inch $(11.43 \mathrm{~cm})$-diameter bioplastic-based biocontainers and a petroleum-based plastic (control) at six greenhouses in the upper midwestern United States. Data were collected when $75 \%$ of plants were in flower at a given greenhouse. Mean separations were performed using Tukey's honestly significant difference test.

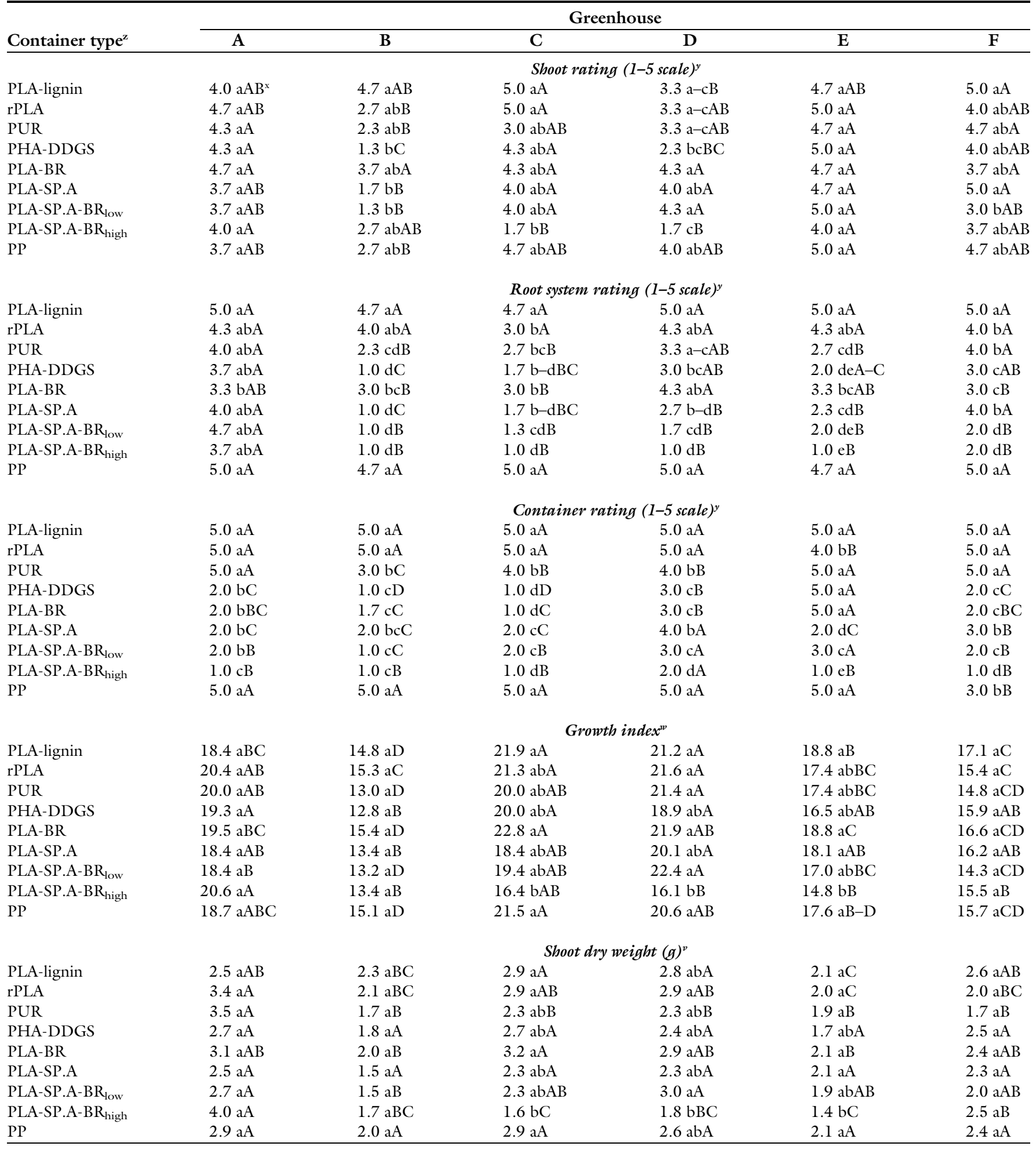

${ }^{\mathrm{z}}$ Containers were manufactured from specific blends of bioplastic or biocomposite materials: PLA = polylactic acid, $\mathrm{BR}=\mathrm{a}$ proprietary bio-based filler derived from dried distiller's grains and solubles, SP.A = soy bioplastic with adipic anhydride, PHA = polyhydroxyalkanoates, DDGS = dried distiller's grains and solubles, rPLA = recycled PLA, $\mathrm{PUR}=$ recycled paper fiber containers twice dip-coated in castor oil-based biopolyurethane, $\mathrm{PP}=$ petroleum-based plastic; $\mathrm{BR}_{\mathrm{low}}$ and $\mathrm{BR}_{\text {high }}$ denote the relative proportion of BR to other container materials.

${ }^{\mathrm{y}}$ Ratings were assigned by commercial grower participants in charge of managing experiments at each greenhouse on a Likert scale: $1=$ worst quality, $2=$ below average quality, $3=$ average quality, 4 = above average quality, 5 = best quality.

${ }^{x}$ Means within columns that share lowercase letters or within rows that share uppercase letters are similar by Tukey's honestly significant difference test at $P \leq 0.05$.

${ }^{\mathrm{w}}$ Growth index $=\{$ plant height $+[($ diameter $1+$ diameter 2$) / 2]\} / 2$.

${ }^{\mathrm{v}} \mathrm{lg}=0.0353 \mathrm{oz}$. 
Table 8. Growth index and shoot quality rating of 'Maverick Red' zonal geranium grown in eight types of 4.5-inch $(11.43 \mathrm{~cm})$-diameter bioplastic-based biocontainers and a petroleum-based plastic (control) at six greenhouses in the upper midwestern United States. Data were collected when $7 \mathbf{5 \%}$ of plants were in flower at a given greenhouse. Data were pooled within container type and across greenhouses, and mean separations were performed using Tukey's honestly significant difference test.

\begin{tabular}{lcc}
\hline Container type $^{\mathrm{z}}$ & ${\text { Shoot rating response }\left(\mathbf{1}-\mathbf{5} \text { scale }^{\mathrm{y}}\right.}^{\mathrm{y}}$ & Growth $_{\text {index }} \mathbf{x}^{\mathbf{x}}$ \\
\hline PLA-lignin & $3.4 \mathrm{~b}^{\mathrm{w}}$ & $20.3 \mathrm{c}$ \\
rPLA & $3.9 \mathrm{ab}$ & $20.3 \mathrm{c}$ \\
PUR & $3.4 \mathrm{~b}$ & $20.3 \mathrm{c}$ \\
PHA-DDGS & $3.5 \mathrm{~b}$ & $19.9 \mathrm{c}$ \\
PLA-BR & $3.7 \mathrm{ab}$ & $21.4 \mathrm{a}-\mathrm{c}$ \\
PLA-SP.A & $4.1 \mathrm{ab}$ & $22.7 \mathrm{a}$ \\
PLA-SP.A-BR & $4.2 \mathrm{a}$ & $22.1 \mathrm{ab}$ \\
PLA-SP.A-BR & $3.9 \mathrm{ab}$ & $22.6 \mathrm{a}$ \\
PP & $3.7 \mathrm{ab}$ & $20.5 \mathrm{bc}$ \\
\hline
\end{tabular}

${ }^{\mathrm{z}}$ Containers were manufactured from specific blends of bioplastic or biocomposite materials: PLA = polylactic acid, $\mathrm{BR}=$ a proprietary bio-based filler derived from dried distiller's grains and solubles, SP.A = soy bioplastic with adipic anhydride, PHA = polyhydroxyalkanoates, DDGS $=$ dried distiller's grains and solubles, $\mathrm{rPLA}=$ recycled PLA, PUR = recycled paper fiber containers twice dip-coated in castor oil-based biopolyurethane, $\mathrm{PP}=$ petroleumbased plastic; $\mathrm{BR}_{\text {low }}$ and $\mathrm{BR}_{\text {high }}$ denote the relative proportion of $\mathrm{BR}$ to other container materials.

${ }^{y}$ Ratings were assigned by commercial grower participants in charge of managing experiments at each greenhouse on a Likert scale: 1 = worst quality, $2=$ below average quality, $3=$ average quality, $4=$ above average quality, $5=$ best quality.

${ }^{\mathrm{x}}$ Growth index $=\{$ plant height $+[($ diameter $1+$ diameter 2$) / 2]\} / 2$

${ }^{w}$ Means within columns that share letters are similar by Tukey's honestly significant difference test at $P \leq 0.05$.

Table 9. Growth index and shoot quality rating of 'Maverick Red' zonal geranium grown in eight types of 4.5-inch $(11.43 \mathrm{~cm})$-diameter bioplastic-based biocontainers and a petroleum-based plastic (control) at six greenhouses in the upper midwestern United States. Data were collected when $75 \%$ of plants were in flower at a given greenhouse. Data were pooled across container type and within greenhouses, and mean separations were performed using Tukey's honestly significant difference test.

\begin{tabular}{|c|c|c|}
\hline Greenhouse & Shoot rating response $(1-5 \text { scale })^{\mathrm{z}}$ & Growth index ${ }^{y}$ \\
\hline A & $4.3 \mathrm{ab}^{\mathrm{x}}$ & $21.4 \mathrm{~b}$ \\
\hline B & $3.3 \mathrm{c}$ & $21.1 \mathrm{~b}$ \\
\hline $\mathrm{C}$ & $3.3 \mathrm{c}$ & $26.6 \mathrm{a}$ \\
\hline $\mathrm{D}$ & $3.8 \mathrm{bc}$ & $18.3 \mathrm{c}$ \\
\hline $\mathrm{E}$ & $4.4 \mathrm{a}$ & $18.3 \mathrm{c}$ \\
\hline $\mathrm{F}$ & $3.4 \mathrm{c}$ & $21.2 \mathrm{~b}$ \\
\hline
\end{tabular}

${ }^{\mathrm{z}}$ Ratings were assigned by commercial grower participants in charge of managing experiments at each greenhouse on a Likert scale: 1 = worst quality, $2=$ below average quality, $3=$ average quality, $4=$ above average quality, $5=$ best quality.

${ }^{y}$ Growth index $=\{$ plant height $+[($ diameter $1+$ diameter 2$) / 2]\} / 2$.

${ }^{\mathrm{x}}$ Means within columns that share letters are similar by Tukey's honestly significant difference test at $P \leq 0.05$.

growth of plants in bioplastic-based biocontainers was comparable to or greater than plants produced in PP containers (Conneway et al., 2015; Helgeson et al., 2009; Koeser et al., 2013b; Lopez and Camberato, 2011). Although a few inconsistencies in plant growth and quality across a few container types were observed, our results suggest that commercial producers would be able to produce high-quality bedding plants in these bioplasticbased biocontainers, under similar greenhouse conditions or cultural practices.
Within each species, growth parameters of angelonia and geraniums differed among greenhouses. This could be expected, given the range in greenhouse environments and cultural practices across facilities (Table 2 ). Growth of angelonia and geranium is affected by PGR applications (Miller and Armitage, 2002; Tayama and Carver, 1990), substrate moisture (Jacobson et al., 2015), fertilizer source, and type of irrigation system (Morvant et al., 2001). This does not, however, explain inconsistencies observed among growth and shoot quality of angelonia in PLA-SP.A-BR high $_{\text {h }}$ containers; shoot quality, GI, and SDW of angelonia grown in PLASP.A-BR high containers were only similar to PP and other container types at three out of six greenhouses. Based on plant growth and quality and substrate-wetness observations made during data collection, we postulate that container materials and moisture-management practices at greenhouses may explain these differences. In a preliminary experiment (data not published), we found that higher substrate moisture content can degrade bioplastic-based containers more rapidly. In addition, in an experiment that investigated pelletized SP.A as a bio-based fertilizer (McCabe et al., 2016a), stunting and chlorosis among 'Honeycomb' marigold (Tagetes patula) and 'Laser Synchro Scarlet' cyclamen (Cyclamen persicum) were observed for plants treated with higher concentrations of SP.A fertilizer. These symptoms were attributed to a rapid release of mineral nutrients as the SP.A material degraded. Although fertilizer was incorporated into the growing medium (McCabe et al., 2016a), research has demonstrated that SP.A-based bioplastic containers release mineral nutrients to plants without container pieces being incorporated into the medium (McCabe et al., 2016b; Schrader et al., 2013). Differences in GI and SDW of angelonia in our experiment existed only for PLA-SP. $\mathrm{A}-\mathrm{BR}_{\text {high }}$ containers, but this reduction in growth was not observed at all greenhouses. We believe poorer root and container ratings among container types manufactured with SP.A support our theory that rapid degradation of SP.A containers at some greenhouses led to a similar stunting of plants observed by McCabe et al. (2016b). Further elucidation of the effects of moisture management on plant growth and bioplastic container materials is needed.

Discrepancies between shoot and root ratings tended to be more prevalent among plants in containers manufactured with SP.A and PHADDGS containers, and less so among plants grown in other container types. For example, angelonia grown in PLA-lignin containers at greenhouse $\mathrm{C}$ received 5 out of 5 shoot ratings and root ratings of 4.7 out of 5 (Table 7); similar trends were observed among PLA-BR, recycled PLA (rPLA), 
Table 10. Grower quality ratings for root systems and containers, and shoot dry weight of growth index (GI), and shoot quality rating of 'Maverick Red' zonal geranium grown in eight types of 4.5 -inch $(11.43 \mathrm{~cm})$-diameter bioplastic containers and a petroleum-based plastic (control) at six greenhouses in the upper midwestern United States. Data were collected when $75 \%$ of plants were in flower at a given greenhouse. Mean separations were performed using Tukey's honestly significant difference test.

\begin{tabular}{|c|c|c|c|c|c|c|}
\hline \multirow[b]{2}{*}{ Container type $^{\mathrm{z}}$} & \multicolumn{6}{|c|}{ Greenhouse } \\
\hline & A & B & C & $\mathrm{D}$ & $\mathbf{E}$ & $\mathbf{F}$ \\
\hline & \multicolumn{6}{|c|}{ Root system rating (1-5 scale) $)^{y}$} \\
\hline PLA-lignin & $3.0 \mathrm{abC}^{\mathrm{x}}$ & $4.0 \mathrm{abB}$ & $5.0 \mathrm{aA}$ & $4.0 \mathrm{abB}$ & $4.0 \mathrm{abB}$ & $4.7 \mathrm{aA}$ \\
\hline rPLA & $3.3 \mathrm{abA}$ & $5.0 \mathrm{aA}$ & $4.0 \mathrm{abA}$ & $5.0 \mathrm{aA}$ & $4.3 \mathrm{aA}$ & $4.3 \mathrm{aA}$ \\
\hline PUR & $3.3 \mathrm{abA}$ & $3.3 \mathrm{bcA}$ & $2.7 \mathrm{abA}$ & $3.3 \mathrm{bcA}$ & $2.7 \mathrm{bcA}$ & $4.3 \mathrm{aA}$ \\
\hline PHA-DDGS & $4.0 \mathrm{abAB}$ & $2.3 \mathrm{cB}$ & $2.0 \mathrm{abB}$ & $4.7 \mathrm{aA}$ & $4.0 \mathrm{abAB}$ & $3.0 \mathrm{aAB}$ \\
\hline PLA-BR & $4.3 \mathrm{aA}$ & $3.0 \mathrm{bcA}$ & $2.7 \mathrm{abA}$ & $3.3 \mathrm{bcA}$ & $4.7 \mathrm{aA}$ & $3.0 \mathrm{aA}$ \\
\hline PLA-SP.A & $2.3 \mathrm{bcAB}$ & $3.7 \mathrm{abcA}$ & $2.7 \mathrm{abAB}$ & $3.0 \mathrm{bcA}$ & $2.7 \mathrm{bcAB}$ & $1.0 \mathrm{bB}$ \\
\hline PLA-SP.A-BR low & $3.3 \mathrm{abA}$ & $3.0 \mathrm{bcA}$ & $2.7 \mathrm{abA}$ & $2.3 \mathrm{cA}$ & $2.0 \mathrm{cdA}$ & $1.0 \mathrm{bA}$ \\
\hline PLA-SP.A-BR high & $1.0 \mathrm{cB}$ & $3.0 \mathrm{bcA}$ & $1.0 \mathrm{bB}$ & $1.0 \mathrm{~dB}$ & $1.0 \mathrm{~dB}$ & $1.0 \mathrm{bB}$ \\
\hline \multirow[t]{2}{*}{ PP } & $1.0 \mathrm{abB}$ & $5.0 \mathrm{aA}$ & $5.0 \mathrm{aA}$ & $5.0 \mathrm{aA}$ & $4.7 \mathrm{aA}$ & $4.7 \mathrm{aA}$ \\
\hline & \multicolumn{6}{|c|}{ Container rating (1-5 scale $)^{y}$} \\
\hline PLA-lignin & $5.0 \mathrm{aA}$ & $5.0 \mathrm{aA}$ & $5.0 \mathrm{aA}$ & $5.0 \mathrm{aA}$ & $4.0 \mathrm{bB}$ & $5.0 \mathrm{aA}$ \\
\hline rPLA & $5.0 \mathrm{aA}$ & $5.0 \mathrm{aA}$ & $5.0 \mathrm{aA}$ & $1.7 \mathrm{dC}$ & $3.0 \mathrm{cB}$ & $5.0 \mathrm{aA}$ \\
\hline PUR & $5.0 \mathrm{aA}$ & $4.7 \mathrm{aA}$ & $3.0 \mathrm{bB}$ & $5.0 \mathrm{aA}$ & $3.0 \mathrm{cB}$ & $5.0 \mathrm{aA}$ \\
\hline PHA-DDGS & $2.0 \mathrm{bD}$ & $3.0 \mathrm{bC}$ & $1.0 \mathrm{dE}$ & $4.0 \mathrm{bB}$ & $5.0 \mathrm{aA}$ & $2.0 \mathrm{dD}$ \\
\hline PLA-BR & $1.0 \mathrm{cC}$ & $2.0 \mathrm{cB}$ & $1.0 \mathrm{dC}$ & $5.0 \mathrm{aA}$ & $5.0 \mathrm{aA}$ & $2.0 \mathrm{~dB}$ \\
\hline PLA-SP.A & $2.0 \mathrm{bB}$ & $1.0 \mathrm{dC}$ & $2.0 \mathrm{cB}$ & $3.0 \mathrm{cA}$ & $2.0 \mathrm{~dB}$ & $3.0 \mathrm{cA}$ \\
\hline PLA-SP.A-BR low & $1.0 \mathrm{cD}$ & $1.0 \mathrm{dD}$ & $1.0 \mathrm{dD}$ & $3.0 \mathrm{cB}$ & $4.0 \mathrm{bA}$ & $2.0 \mathrm{dC}$ \\
\hline PLA-SP.A-BR high & $1.0 \mathrm{cC}$ & $1.0 \mathrm{dC}$ & $1.0 \mathrm{dC}$ & $5.0 \mathrm{aA}$ & $4.0 \mathrm{bB}$ & $1.0 \mathrm{eC}$ \\
\hline \multirow[t]{2}{*}{ PP } & $5.0 \mathrm{aA}$ & $5.0 \mathrm{aA}$ & $5.0 \mathrm{aA}$ & $4.0 \mathrm{bB}$ & $4.0 \mathrm{bB}$ & $4.0 \mathrm{bB}$ \\
\hline & \multicolumn{6}{|c|}{ Shoot dry weight $(g)^{w}$} \\
\hline PLA-lignin & $6.2 \mathrm{aABC}$ & $7.6 \mathrm{aAB}$ & $8.8 \mathrm{aA}$ & $3.7 \mathrm{abC}$ & $5.1 \mathrm{aBC}$ & $5.6 \mathrm{aBC}$ \\
\hline rPLA & $6.1 \mathrm{aAB}$ & $7.3 \mathrm{aA}$ & $6.5 \mathrm{aAB}$ & $4.1 \mathrm{abB}$ & $5.5 \mathrm{aAB}$ & $7.2 \mathrm{aA}$ \\
\hline PUR & $7.2 \mathrm{aA}$ & $6.0 \mathrm{aA}$ & $6.0 \mathrm{aA}$ & $3.4 \mathrm{abB}$ & $5.2 \mathrm{aAB}$ & $7.2 \mathrm{aA}$ \\
\hline PHA-DDGS & $5.8 \mathrm{aB}$ & $6.3 \mathrm{aB}$ & $9.0 \mathrm{aA}$ & $2.9 \mathrm{bC}$ & $5.3 \mathrm{aB}$ & $6.2 \mathrm{aB}$ \\
\hline PLA-BR & $7.4 \mathrm{aAB}$ & $7.1 \mathrm{aAB}$ & $9.0 \mathrm{aA}$ & $3.7 \mathrm{abC}$ & $5.7 \mathrm{aBC}$ & $8.0 \mathrm{aAB}$ \\
\hline PLA-SP.A & $5.9 \mathrm{aBC}$ & $7.1 \mathrm{aB}$ & $9.2 \mathrm{aA}$ & $4.4 \mathrm{aC}$ & $5.3 \mathrm{aBC}$ & $6.7 \mathrm{aB}$ \\
\hline PLA-SP.A-BR low & $9.3 \mathrm{aA}$ & $8.5 \mathrm{aA}$ & $8.6 \mathrm{aA}$ & $3.8 \mathrm{abB}$ & $5.0 \mathrm{aAB}$ & $6.1 \mathrm{aAB}$ \\
\hline PLA-SP.A-BR high & $8.0 \mathrm{aA}$ & $7.2 \mathrm{aAB}$ & $7.5 \mathrm{aAB}$ & $3.4 \mathrm{abC}$ & $4.5 \mathrm{aBC}$ & $7.8 \mathrm{aA}$ \\
\hline $\mathrm{PP}$ & $5.8 \mathrm{aAB}$ & $7.5 \mathrm{aA}$ & $7.9 \mathrm{aA}$ & $3.5 \mathrm{abB}$ & $5.6 \mathrm{aAB}$ & $6.7 \mathrm{aA}$ \\
\hline
\end{tabular}

${ }^{\mathrm{z}}$ Containers were manufactured from specific blends of bioplastic or biocomposite materials: PLA = polylactic acid, $\mathrm{BR}=$ a proprietary bio-based filler derived from dried distiller's grains and solubles, SP.A = soy bioplastic with adipic anhydride, PHA = polyhydroxyalkanoates, DDGS = dried distiller's grains and solubles, rPLA = recycled $\mathrm{PLA}, \mathrm{PUR}=$ recycled paper fiber containers twice dip-coated in castor oil-based biopolyurethane, $\mathrm{PP}=$ petroleumbased plastic; $\mathrm{BR}_{\text {low }}$ and $\mathrm{BR}_{\text {high }}$ denote the relative proportion of $\mathrm{BR}$ to other container materials.

${ }^{\mathrm{y}}$ Ratings were assigned by commercial grower participants in charge of managing experiments at each greenhouse on a Likert scale: 1 = worst quality, 2 = below average quality, 3 = average quality, 4 = above average quality, $5=$ best quality.

${ }^{\mathrm{x}}$ Means within columns that share lowercase letters or within rows that share uppercase letters are similar by Tukey's honestly significant difference test at $P \leq 0.05$.

${ }^{w} 1 \mathrm{~g}=0.0353 \mathrm{oz}$.

and PUR containers as well. Alternatively, shoots of angelonia grown in PLA-SP.A containers at greenhouse C were rated 4.0 out of 5 , whereas roots were rated 1.7 (Table 7 ). This contradicts Schrader et al. (2015), who found SP.A-based containers promoted a denser and more fibrous root system than did PP controls. Research has shown that roots of plants produced in SP.A-based containers have increased branching and to the container sidewalls. This likely contributed to lower root ratings for this container type among both angelonia and geranium. This suggests that containers manufactured without SP.A or PHA-DDGS may be particularly acceptable commercially.

Ratings of PLA-lignin, rPLA, and PUR containers were almost always similar to those of PP, and were highest overall across all bioplastic container types. Container-rating trends resembled those observed among root ratings for both species. All containers with SP.A and PHADDGS received lower ratings than other container types overall (Tables 7 and 10). We believe that differences in container quality resulted from an interaction of container type and the use of shuttle trays in production. Schrader et al. (2015) characterized the horticultural suitability of prototype versions of the containers we used, which were categorized based on performance and biodegradability. Containers manufactured with PLA and SP.A, PHA-DDGS, and twice dip-coated polyurethane paper fiber degraded $30 \%$ to $45 \%, 47 \%$, or $12 \%$ after 6 months in soil, respectively, and were deemed biodegradable in soil within 1-2 years. Conversely, containers manufactured with a combination of PLA and lignin or only rPLA were considered durable, an improvement in sustainability compared with PP, and requiring few changes to cultural practices; these container types did not degrade in soil after 6 months. Our results suggest that the use of biodegradable bioplastic-based containers (biodegradable in soil in 1-2 years) will require adequate management of substrate moisture (growing drier), as decomposition of materials used to manufacture these containers is enhanced by increased humidity, temperature, and the presence of microorganisms found in soil and water (Grewell et al., 2014; Lu et al., 2014).

Preproduction questionnaires revealed that commercial grower participants were interested in using bioplastic containers before experiment initiation (Table 3). Participants had previously used biocontainers in their production schemes (data not shown); however, we did not identify any bias among grower participants that would have influenced responses to questionnaires or Likert scale ratings. Postproduction questionnaires also demonstrated that use of 
these containers in their commercial production systems did not affect their perceptions or interest in using them in future, and impressions remained positive. In addition, these bioplastic and biocomposite containers exceeded expectations and growers were in favor of producing plants in them (Table 4). These findings suggest that our grower participants had confidence in their ability to implement these containers on a larger scale. Hall et al. (2009) identified that concerns surrounding ease of implementation are the most significant barrier to adoption of sustainable technologies among commercial floriculture producers. Responses to our questionnaires suggest this may not be an issue for bioplastic-based biocontainers. Grower responses (Table 5) also support the assertion that properties of these bioplastic-based plant containers are desirable among commercial producers. Questions regarding biocontainer attributes (Table 5) were designed to evaluate commercial container crop producers' interest in additional container functions; however, responses to these questions may be relevant to floriculture retailers as well.

The factors we have examined ultimately illustrate key differences in the functionality of certain bioplastic and biocomposite containers in greenhouse crop production settings and emphasize that producers should select containers based on their parent materials to best suit their needs. Containers such as PLA-BR, PLA-lignin, rPLA, and PUR can be easily integrated into commercial production schemes owing to their durability, but the attributes favored among producers may hamper their functionality as biodegradable alternatives to single-use PP pots (Schrader et al., 2015). Alternatively, containers manufactured using SP.A or PHADDGS more closely meet the requirements that consumers look for in a biocontainer, but use of these will likely require producers to adjust their crop-production practices.

\section{Conclusions}

The bioplastic-based biocontainers we used generally supported plants of similar size and quality to those in standard PP containers. Growth of angelonia and geranium was minorly affected by container type, and grower-perceived shoot and root quality exhibited similar trends. Differences observed in plant size and quality likely resulted from container type interacting with environment and/or production practices. Only plants produced in PHA-DDGS and containers made with both PLA and SP.A were smaller or of lower quality than other container types, although these differences were not observed within all greenhouses. Producer perceptions of and attitudes toward these containers were positive, and growers were interested in implementing the use of containers such as these in their commercial production schemes in the future. Our results demonstrate that interest in and use of bioplasticbased containers that biodegrade easily in soil or compost may need to be balanced against the consideration that slightly more effort may be required for managing moisture conditions during crop production. Overall, results of this experiment suggest that these bioplastic-based biocontainers are viable alternatives to PPs in containerized production of annual bedding plants.

\section{Literature cited}

Chappell, M., S.K. Dove, M. van Iersel, P.A. Thomas, and J. Ruter. 2013. Implementation of wireless sensor networks for irrigation control in three container nurseries. HortTechnology 23:747-753.

Conneway, R., S. Verlinden, A.K. Koeser, M.R. Evans, R. Schnelle, V. Anderson, and J.R. Stewart. 2015. Use of alternative containers for long- and short-term greenhouse crop production. HortTechnology 25:26-34.

Currey, C., K.G. McCabe, J. Schrader, W. Graves, J. Behrens, and D. Grewell. 2015. Biocontainers 2.0. GrowerTalks 79(5):7478.

Evans, M.R. and D. Hensley. 2004. Plant growth in plastic, peat, and processed poultry feather fiber growing containers. HortScience 39:1012-1014.

Evans, M.R., A.K. Koeser, G. Bi, S. Nambuthiri, R. Geneve, S.T. Lovell, and J.R. Stewart. 2015. Impact of biocontainers with and without shuttle trays on water use in the production of a containerized ornamental greenhouse crop. HortTechnology 25:35-41.

Evans, M.R., M. Taylor, and J. Kuehny. 2010. Physical properties of biocontainers for greenhouse crops production. HortTechnology 20:549-555.
Grewell, D., G. Srinivasan, J. Schrader, W. Graves, and M. Kessler. 2014. Sustainable materials for horticultural application. Plast. Eng. 70:44-52.

Hall, C.R., B.L. Campbell, B.K. Behe, C. Yue, R.G. Lopez, and J.H. Dennis. 2010. The appeal of biodegradable packaging to floral consumers. HortScience 45:583591.

Hall, T.J., J.H. Dennis, R.G. Lopez, and M. I. Marshall. 2009. Factors affecting growers' willingness to adopt sustainable floriculture practices. HortScience 45:1346-1351.

Helgeson, M., W.R. Graves, D. Grewell, and G. Srinivasan. 2009. Degradation and nitrogen release of zein-based bioplastic containers. J. Environ. Hort. 27:123127.

Jacobson, A.B., T.W. Starman, and L. Lombardini. 2015. Substrate moisture content effects on growth and shelf life of Angelonia angustifolia. HortScience 50:272-278.

Jeong, K.Y., B. Whipker, I. McCall, and J. Frantz. 2009. Gerbera leaf tissue nutrient sufficiency ranges by chronological age. Acta Hort. 843:183-190.

Koeser, A.K., G. Kling, C. Miller, and D. Warnock. 2013a. Compatibility of biocontainers in commercial greenhouse crop production. HortTechnology 23:149156.

Koeser, A.K., S.T. Lovell, M.R. Evans, and R. Stewart. 2013b. Biosontainer water use in short-term greenhouse crop production. HortTechnology 23:215219.

Kratsch, H.A., J.A. Schrader, K.G. McCabe, G. Srinivasan, D. Grewell, and W.R. Graves. 2015. Performance and biodegradation in soil of novel horticulture containers made from bioplastics and biocomposites. HortTechnology 25:119131 .

Kuehny, J.S., M. Taylor, and M.R. Evans. 2011. Greenhouse and landscape performance of bedding plants in biocontainers. HortTechnology 21:155-161.

Liu, K., S.A. Madbouly, J.A. Schrader, M.R. Kessler, D. Grewell, and W.R. Graves. 2015. Biorenewable polymer composites from tall oil-based polyamide and lignin-cellulose fiber. J. Appl. Polym. Sci. 132:42592.

Lopez, R.G. and D. Camberato. 2011. Growth and development of 'Eckespoint Classic Red' poinsettia in biodegradable and compostable containers. HortTechnology 21:419-423.

Lu, H., S.A. Madbouly, J.A. Schrader, M.R. Kessler, D. Grewell, and W.R. Graves. 2014. Novel bio-based composites 
of polyhydroxyalkanoate (PHA)/distillers dried grains with solubles (DDGS). RSC Advances 4:39802-39808.

Madbouly, S., H. Lu, J.A. Schrader, G. Srinivasan, K.G. McCabe, D. Grewell, W.R. Graves, and M.R. Kessler. 2014. Biodegradation behavior of poly(lactic acid) (PLA)/distiller's dried grains with solubles (DDGS) composites. ACS Sustain. Chem.\& Eng. 2:2699-2706.

McCabe, K.G., C.J. Currey, J.A. Schrader, D. Grewell, J. Behrens, and W.R. Graves. 2016a. Pelletized soy-based bioplastic fertilizers for container-crop production. HortScience 51:1417-1426.

McCabe, K.G., J.A. Schrader, C.J. Currey, D. Grewell, and W.R. Graves. 2016b. Soycomposite biocontainers allow for reduced fertilizer inputs during container-crop production. HortScience 51:927-934.

McCabe, K.G., J.A. Schrader, S. Madbouly, D. Grewell, and W.R. Graves. 2014. Evaluation of biopolymer-coated fiber containers for container-grown plants. HortTechnology 24:439-448.
Meng, Q. and E.S. Runkle. 2014. Controlling flowering of photoperiodic ornamental crops with light-emitting diode lamps: A coordinated grower trial. HortTechnology 24:702-711.

Miller, A. and A.M. Armitage. 2002. Temperature, irradiance, photoperiod, and growth retardants influence greenhouse production of Angelonia angustifolia 'Angel Mist' series. HortScience 37:319-321.

Morvant, J.K., J. Dole, and J.C. Cole. 2001. Fertilizer source and irrigation system affect geranium growth and nitrogen retention. HortScience 36:1022-1026.

Schrader, J.A. 2013. Report on the annual consumption of plastics for specialty- crop containers in the United States. 25 Mar. 2016. <http://www.public.iastate.edu/ $\sim$ bioplastic/Supplementary/AnnualPlastic. html>.

Schrader, J.A., K.G. McCabe, G. Srinivasan, K. Haubrich, D. Grewell, S. Madbouly, and W.R. Graves. 2015. Development and evaluation of bioplastic containers for sustainable greenhouse and nursery production. Acta Hort. 1104:79-88.

Schrader, J.A., G. Srinivasan, D. Grewell, K.G. McCabe, and W.R. Graves. 2013. Fertilizer effects of soy-plastic containers during crop production and transplant establishment. HortScience 48:724-773.

Tayama, H.K. and S.A. Carver. 1990. Zonal geranium growth and flowering responses to six growth regulators. HortScience 25:82-83.

U.S. Department of Agriculture. 2015. Census of horticultural specialties 2014. 25 Mar. 2016. <http://www.agcensus. usda.gov/Publications/2012/Online_ Resources/Census_of_Horticulture_ Specialties/HORTIC.pdf $>$.

Yang, S., S.A. Madbouly, J.A. Schrader, G. Srinivasan, D. Grewell, K.G. McCabe, M.R. Kessler, and W.R. Graves. 2015. Characterization and biodegradation behavior of bio-based poly(lactic acid) and soy protein blends for sustainable horticultural applications. Green Chem. 17:380-393. 